Article

\title{
Egg Yolk Antioxidants Profiles: Effect of Diet Supplementation with Linseeds and Tomato-Red Pepper Mixture before and after Storage
}

\author{
Besma Omri ${ }^{1,2}$, Nadir Alloui ${ }^{3}$, Alessandra Durazzo ${ }^{4}{ }^{\circ}$, Massimo Lucarini ${ }^{4}$, \\ Alessandra Aiello ${ }^{5}\left(\mathbb{D}\right.$, Raffaele Romano ${ }^{5}\left(\mathbb{D}\right.$, Antonello Santini ${ }^{6, *}{ }^{(1)}$ and Hedi Abdouli ${ }^{1}$ \\ 1 Laboratory of Improvement \& Integrated Development of Animal Productivity \& Food Resources, \\ Higher School of Agriculture of Mateur, University of Carthage, Avenue de la République P.O. Box 77, \\ Amilcar 1054, Tunisia \\ 2 National Agronomy Institute, Tunis, University of Carthage, Avenue de la République P.O. Box 77, \\ Amilcar 1054, Tunisia \\ 3 Department of Veterinary Sciences, University of Batna, Batna 05000, Algeria \\ 4 CREA-Research Centre for Food and Nutrition, Via Ardeatina 546, 00178 Roma, Italy \\ 5 Department of Agriculture, University of Napoli Federico II, 80138 Napoli, Italy \\ 6 Department of Pharmacy, University of Napoli Federico II, Via D. Montesano 49, 80131 Napoli, Italy \\ * Correspondence: asantini@unina.it; Tel.: +39-81-253-9317
}

Received: 24 June 2019; Accepted: 30 July 2019; Published: 7 August 2019

\begin{abstract}
This study evaluated the effect of dietary incorporation of linseed alone or along with dried tomato paste-pepper powder mix on egg physical characteristics, antioxidant profiles, lipid oxidative status, and yolk coloration before and after storage at $4{ }^{\circ} \mathrm{C}$ for one month. Sixty Novogen White laying hens, 27 weeks-old, were divided into three groups and given $100 \mathrm{~g} /$ hen/day of a standard diet (C), standard diet containing $4.5 \%$ of ground linseed (L), linseed diet containing $1 \%$ of dried tomato paste and $1 \%$ of sweet red pepper (LTP). Linseeds increased $(p<0.05)$ egg yolk antioxidant capacity but not lipid oxidative stability $(p>0.05)$. However, dietary inclusion of LTP did not improve fresh egg yolk antioxidant activity and lipid oxidation stability $(p>0.05)$. With reference to the stored eggs, only antioxidant activity measured by phosphomolybdenum reduction and lipid oxidative stability were influenced $(p<0.05)$ by the dietary treatment. Fresh egg yolk of hens fed on linseeds tended to have a slightly more yellow, redder, and less light color than the eggs of hens fed with the control diet. Dietary supplementation of LTP increased $(p<0.05)$ the Roche yolk color fan (RYCF) score and redness $\left(\mathrm{a}^{*}\right)$ and decreased $(p<0.05)$ lightness $\left(\mathrm{L}^{*}\right)$ without affecting $(p>0.05)$ saturation $\left(\mathrm{C}^{*}\right)$. Storage of hens' eggs fed on the control diet did not influence $(p>0.05)$ yolk color.
\end{abstract}

Keywords: carotenoid; flavonoids; oxidative status; polyphenols; yolk color

\section{Introduction}

The hen's egg is considered as a functional food, since it represents a valuable source of high quality proteins, minerals, vitamins, and lipids, i.e., polyunsaturated fatty acids (PUFA) and phospholipids [1-6]. Beside their nutritional value, eggs represent a good source of antioxidants [6]: egg proteins (i.e., ovalbumin, ovotransferrin, phosvitin), phospholipids, and vitamin A, vitamin E, selenium, carotenoid, show antioxidant [7-16] and nutraceuticals properties [13-27].

Moreover, eggs can be also enriched with antioxidants by manipulation of poultry feed [28-32]. Omega-3 fatty acids and carotenoids are biologically active compounds utilized for egg biofortification [33,34] also using by-products of agro system chain in an environmentally friendly way [34-40]. 
Carotenoid [41] can be supplemented as dried synthetic pigments or as natural pigments from red pepper [42], tomato powder [36,37,43-45] and colored carrot [46]. They cannot be produced by hens de novo. Carotenoid must be provided in their diet's ingredients [47]. These compounds were used as pigments for many years so as to obtain a desired color of egg yolk [48]. Egg choice by consumers is no longer only based on yolk cholesterol content or fatty acids profile, but also on its color [49] due to the health benefits associated with the pigment source [50-52]. As antioxidants [53], carotenoids, were used to neutralize the excess of free radicals, to protect the cell against their toxic effects and to contribute to disease prevention such as arthrosclerosis, cardiac hypertrophy, congestive heart failure and Alzheimer [54-57]. For example, according to Willcox et al. [54] beta-carotene is a strong antioxidant and is the best quencher of singlet oxygen. Lycopene, a carotenoid, has been found to be very protective, particularly for prostate cancer [55]. The current review of Bohn [56] well summarizes human observational studies/intervention trials targeting carotenoids in relation to chronic diseases characterized by oxidative stress and markers thereof: the author underlines, that, even if different markers of oxidative stress were studied, no single one gives a complete shot of oxidative stress homeostasis, related to the involvement of many body compartments, mechanisms and the type/number of bioactive compounds.

It is worth mentioning the review of Pham-Huy et al. [57] on the role of antioxidants in the prevention of chronic diseases such as cancer, autoimmune disorders, aging, cataract, rheumatoid arthritis, cardiovascular and neurodegenerative disease; antioxidants present different physiological properties, i.e., anti-allergic, antimicrobial, anti-inflammatory, anti-atherogenic, vasodilatory effects [58-64].

Also, the current work of Yeung et al. [65] reported, by means of a scientific literature analysis of works since 1991, that there has been a transition of scientific interest from vitamins and minerals to antioxidant phytochemicals.

Red pepper, the source of red and yellow carotenoid [66,67], used at $0.8 \%$, increased egg yolk color scores [42]. However, dried tomato contained lycopene, the main red carotenoid responsible for egg yolk red color. The combination of red and yellow carotenoid has been found to be effective for yolk pigmentation [68]. Yellow carotenoid deposition creates a yellow base, which is necessary for the saturation of the final color. When the saturated phase was established, red carotenoid addition increased the orange-red yolk color. Furthermore, feeding hens with linseed, sunflower and palm oil accelerated egg yolk lipid oxidation, related to long chain polyunsaturated fatty acids [69].

Lipid oxidation is a process that affects egg yolk lipid stability during storage. It can alter egg nutritional quality and may lead to taste, flavor, odor and color depreciation and to toxic substances production [70,71]. Prevention of cholesterol oxidation and PUFA auto-oxidation could be reached by carotenoid supplementation, tomatoes or sweet red pepper, as sources of antioxidants into hens' feed.

The use of linseeds, tomato by-products or red pepper as natural or biological feed additives has been done to supplement laying hens' feeds, and consequently, the egg industry, with essential micro-ingredients (polyunsaturated fatty acids ( $\omega-3$ and $\omega-6)$ and antioxidant $(\alpha$-carotene, $\beta$-carotene, $\beta$-cryptoxanthine, lycopene, zeaxanthin, total phenols and flavonoids), as well as for animal wellbeing purposes and improved efficiency. As far as red pepper is concerned, Li et al. [41] reported that the development of an environmental friendly technique which would allow the egg yolk coloring ability of red peppers to be obtained at a lower cost with enhanced efficiency could be extremely beneficial to the poultry industry; moreover, this result has led to an increase of interest of consumers.

Dietary supplementation of tomato by-products or red pepper was also a new solution to optimize livestock economic (reducing the prices of feed ingredients) and environmental performance at the industry level. This supplementation may reduce the need for synthetic antioxidants at industry level through advanced knowledge of the impact of these ingredients and their composition on animal and human health and the use of natural antioxidant to optimize the safety, sustainability and nutritional value of feed ingredients; moreover this result has led to an increase of interest from consumer. 
In view of the above, the present study aims at evaluating the effect of dietary incorporation of linseed alone or along with a dried tomato paste-pepper powder mix on egg physical characteristics, egg yolk antioxidant profile, lipid oxidative status and coloration before and after storage at $4{ }^{\circ} \mathrm{C}$ for one month.

\section{Materials and Methods}

\subsection{Ethical Considerations}

All procedures concerning animals' care, handling, and sampling were conducted under the approval of the Official Animal Care and Use Committee of the Higher School of Agriculture of Mateur (protocol $\mathrm{N}^{\circ} 05 / 15$ ) before the initiation of the study and followed the Tunisian guidelines.

\subsection{Experimental Design}

A total of sixty, Novogen White laying hens (initial live weight $=1449.95 \mathrm{~g} \pm 71.99 \mathrm{~g}$ ) of 27 weeks-old were randomly regrouped into 3 homogeneous groups of 20 hens each. Corn and soybean-meal were used as a standard mash diet $(C)$ for laying hens. Two supplemented diets were designated as follows: (1) linseed (L) and (2) linseed-tomato-pepper (LTP), which were individually prepared by mixing the control diet thoroughly with the designated supplements at the required incorporation levels, as described by Omri et al. [72] (Table 1).

Table 1. Ingredients, chemical and antioxidants composition of the experimental diet $(\mathrm{g} / \mathrm{Kg})$ *

\begin{tabular}{|c|c|c|c|}
\hline & & & Diets \\
\hline & Control (C) & Linseeds (L) & $\begin{array}{c}\text { Linseeds-Tomato-Pepper } \\
\text { (LTP) }\end{array}$ \\
\hline \multicolumn{4}{|l|}{ Ingredients (\%) } \\
\hline Linseed & 0 & 4.5 & 4.5 \\
\hline Dried Tomato & 0 & 0 & 1 \\
\hline Sweet red pepper & 0 & 0 & 1 \\
\hline Yellow corn & 66.5 & 63.5 & 61.5 \\
\hline Soybean meal & 25.5 & 24.0 & 24.0 \\
\hline $\begin{array}{c}\text { Calcium carbonate, Mineral and } \\
\text { Vitamin mixture }\end{array}$ & 8.0 & 8.0 & 8.0 \\
\hline \multicolumn{4}{|l|}{ Chemical Composition } \\
\hline Crude protein, $(\%$, dry matter $(\mathrm{DM}))$ & 18.1 & 18 & 18 \\
\hline Ether extract $(\%, D M)$ & 3.56 & 5.6 & 5.27 \\
\hline Metabolizable energy (Kcal/Kg DM) & 2750 & 2850 & 2830 \\
\hline \multicolumn{4}{|l|}{ Antioxidants } \\
\hline$\alpha$-carotene, ${ }^{*}\left(10^{-9}\right) \mathrm{g} / \mathrm{kg} \mathrm{DM}$ & 3.41 & 5.1 & 21.7 \\
\hline$\beta$-carotene, ${ }^{*}\left(10^{-9}\right) \mathrm{g} / \mathrm{kg} \mathrm{DM}$ & 3.37 & 5.36 & 23.2 \\
\hline$\beta$-cryptoxanthine, ${ }^{*}\left(10^{-9}\right) \mathrm{g} / \mathrm{kg} \mathrm{DM}$ & 3.84 & 5.50 & 25.3 \\
\hline Lycopene, ${ }^{*}\left(10^{-9}\right) \mathrm{g} / \mathrm{kg}$ DM & 1.77 & 3.48 & 15.7 \\
\hline Zeaxanhine, ${ }^{*}\left(10^{-9}\right) \mathrm{g} / \mathrm{kg} \mathrm{DM}$ & 3.90 & 5.59 & 25.7 \\
\hline${ }^{£}$ Flavonoids, g CE/kg DM & 2.26 & 1.59 & 2.03 \\
\hline$¥$ Total phenols, g GAE/kg DM & 3.02 & 3.53 & 2.98 \\
\hline
\end{tabular}

${ }^{*}$ Note: $\mathrm{C}=$ Control diet; $\mathrm{L}=$ diet supplemented with ground linseed at $4.5 \%, \mathrm{LTP}=$ diet supplemented with ground linseed (4.5\%), dried tomato paste (1\%) and sweet pepper powder $(1 \%)$ mix; ${ }^{*}$ Total phenols expressed in g gallic acid equivalent, g GAE $/ \mathrm{kg} \mathrm{DM}$; ${ }^{£}$ Flavonoids expressed in g catechin equivalent, g CE/kg DM. Control (C) provided following nutrients per $100 \mathrm{~g}$ : Ca, $4.3 \mathrm{~g} ; \mathrm{P}, 0.6 \mathrm{~g}$; Na, $0.14 \mathrm{~g}$; Cl, $0.23 \mathrm{~g}$; $\mathrm{Fe}, 4 \mathrm{mg}$; $\mathrm{Zn}, 40 \mathrm{mg} ; \mathrm{Mn}, 7 \mathrm{mg} ; \mathrm{Cu}, 0.3 \mathrm{mg}$; I, $0.08 \mathrm{mg}$; Se, $0.01 \mathrm{mg}$; Co, 0.02; methionine, $0.39 \mathrm{~g}$; methionine + cysteine, $0.69 \mathrm{~g}$; lysine, $0.89 \mathrm{~g}$; Retinol, $800 \mathrm{IU}$; Cholecalciferol, 220 IU; $\alpha$-tocopherol, 1.1 IU; Thiamin, 0.33 IU; Nicotinic acid, 909 IU.

To reduce the feed-selection behavior typically observed in laying hens diets were restricted to $100 \mathrm{~g} / \mathrm{hen} / \mathrm{d}$. Feed was offered once daily at 7:30 AM. Hens were allocated individually in standard 
pens with individual feed-trough and common water-trough in an ambient temperature of about $20 \pm 4{ }^{\circ} \mathrm{C}$. A lighting schedule of $16 \mathrm{~h}$ light and $8 \mathrm{~h}$ dark was followed. Water was offered ad libitum. during the experimental period, which lasted 47 days.

\subsection{Data Collection and Chemical Analyses}

Eggs laid from the 26th to the 30th days of the experimental period were weighed and used for egg physical characteristics measurements (egg albumen, yolk and shell weights). Egg yolks were pooled per two hens belonging to the same dietary treatment group so that 10 yolk samples per group were obtained instead of 20. Yolk samples were then used for analyses: antioxidant profile, oxidative status and egg yolk color. Eggs laid during the 31st day of the experimental trial were weighted and stored at $4{ }^{\circ} \mathrm{C}$ for one month. After storage, the eggs were used for the same analyses as those conducted prior to storage.

\subsection{Egg Yolk Color}

Egg yolk color was determined using the Yolk Color Fan ${ }^{\circledR}$ Scale DSM Yolk Color Fan (DSM Nutritional Products Europe, Wurmisweg 576, CH-4303 Kaiseraugst, Switzerland) (1 for light yellow and 15 for orange) and the color measuring device Konica Minolta Chroma Meter CR- 400/410 (Minolta, Tokyo, Japan) following the CIE (Commission Internationale de L'Eclairage) color system, L* (lightness: negative towards black, positive towards white) $\mathrm{a}^{*}$ (redness: negative towards green, positive towards red) and $b^{*}$ (yellowness: negative towards blue, positive towards yellow). Chroma Meter was set up perpendicularly to the egg yolk surface in a Petri dish. $\mathrm{L}^{*}, \mathrm{a}^{*}$ and $\mathrm{b}^{*}$ parameters were measured three times. Final values were calculated as the averages of the three corresponding values measured.

Egg chroma was calculated according to the formula:

$$
C^{*}=\left(a^{*} 2+b^{*} 2\right)^{1 / 2}
$$

\subsection{Antioxidant Profile Determination}

\subsubsection{Total Carotenoid Determination}

Total carotenoid of fresh, stored egg yolk and diets were determined in accordance with Amaya, [73]. Samples of $0.5 \mathrm{~g}$ were extracted in $5 \mathrm{~mL}$ of Butylated Hydroxy Toluene (BHT) $(0.05 \%)$ in cold acetone $\left(4{ }^{\circ} \mathrm{C}\right)$ and stirred for $1 \mathrm{~h} 30 \mathrm{~min}$. After $15 \mathrm{~min}$ of centrifugation at $3000 \mathrm{rpm}$, the supernatant was transferred to another tube containing $7 \mathrm{~mL}$ of petroleum ether.

Then $20 \mathrm{~mL}$ of distilled water was slowly added along the tube. After separation of two phases for $1 \mathrm{~h}, 10 \mathrm{~mL}$ of distilled water was added. The aqueous phase was discarded. The ether phase was transferred to another tube and absorbance was measured.

\subsubsection{Total Phenol Determination}

The Folin-Ciocalteu method following the procedure of Makkar et al. [74] was used for total phenol content of acetone extracts evaluation. A total of $1 \mathrm{~mL}$ of acetone extract was mixed with $0.5 \mathrm{~mL}$ of Folin-Ciocalteu reagent, then $2.5 \mathrm{~mL}$ of $\mathrm{Na}_{2} \mathrm{CO}_{3}$ solution $(20 \% w / v)$ were added. The solution was incubated for $40 \mathrm{~min}$ at $60^{\circ} \mathrm{C}$ after vortexing and absorbance was measured at $750 \mathrm{~nm}$ against a blank (distilled water). Total phenolics content was expressed as mg equivalents gallic acid (EGA) (standard) per $g$ of sample.

\subsubsection{Flavonoid Determination}

Flavonoid content was determined by the aluminum chloride method as reported by Patel et al. [75]. Fresh, stored egg yolk or diet samples $(100 \mathrm{mg})$ were extracted in $5 \mathrm{~mL}$ of diethyl. After centrifugation for $15 \mathrm{~min}$ at $2000 \mathrm{rpm}$, the precipitate was extracted in $5 \mathrm{~mL}$ of $80 \%$ methanol for $5 \mathrm{~h}$ and filtered using Wathman filter paper. The filtrate was adjusted to $50 \mathrm{~mL}$ with distilled 
water. An Aliquot of $2.5 \mathrm{~mL}$ was mixed with $0.15 \mathrm{~mL} \mathrm{NaNO} 2$ (5\%). After $5 \mathrm{~min}, 0.15 \mathrm{~mL}$ of aluminum chloride $(10 \%)$ was added. Six minutes later, $1 \mathrm{~mL}$ of $\mathrm{NaOH}(1 \mathrm{~N})$ and $1.2 \mathrm{~mL}$ of distilled water were added. The solution was vortexed and absorbance was measured at $510 \mathrm{~nm}$ against distilled water (blank). The flavonoid content was expressed as mg equivalents catechin (standard) per g of sample.

\subsubsection{Oxidative Status Determination}

Antioxidant activity [76,77] of fresh and stored egg yolk was measured by the phosphomolybdenum method according to the procedure described by Prieto et al. [78]. A total of $0.5 \mathrm{~g}$ of fresh egg yolk was diluted in $10 \mathrm{~mL}$ of $\mathrm{NaCl}(2 \%)$. A total of $100 \mu \mathrm{L}$ of the suspension was adjusted to $2 \mathrm{~mL}$ with distilled water. Then, $2 \mathrm{~mL}$ of phosphomolybdenum reagent ( $2.8 \mathrm{mM}$ of sodium phosphate and $4 \mathrm{mM}$ ammonium molybdate in $0.6 \mathrm{M}$ sulphuric acid) was added. After incubation at $95^{\circ} \mathrm{C}$ for $90 \mathrm{~min}$., the mixture was cooled at room temperature and the absorbance was measured at $695 \mathrm{~nm}\left(\mathrm{~A}_{695 \mathrm{~nm}}\right)$ using a UV-visible spectrophotometer (CECIL Auruis series CE $\left.2041 \mathrm{UV} / \mathrm{Vis}\right)$ against $2 \% \mathrm{NaCl}$ (blank). Antioxidant capacity is expressed as mg equivalents of ascorbic acid (EAA) (standard) per g of sample.

Total antioxidant activity was also evaluated by ferric reducing antioxidant power assay, according to Benzie and Szeto [79], with slight modifications. Aqueous solutions of egg yolk prepared as reported above were used for this assay. A total of $150 \mu \mathrm{L}$ of solution was mixed with $2.4 \mathrm{~mL}$ of distilled water, $0.45 \mathrm{~mL}$ of ethanol, $0.75 \mathrm{~mL}$ of $\mathrm{HCl}, 0.75 \mathrm{~mL}$ of $1 \%$ potassium ferricyanide, $0.25 \mathrm{~mL}$ of $1 \% \mathrm{SDS}$ and $0.25 \mathrm{~mL}$ of $0.2 \%$ ferric chloride. The solution was left in a water bath at $50{ }^{\circ} \mathrm{C}$ for $20 \mathrm{~min}$ then cooled at room temperature and absorbance was measured at $750 \mathrm{~nm}$. Antioxidant capacity is expressed as $\mathrm{mg}$ Equivalents Gallic Acid (EGA) (standard) per g of sample.

The malondialdehyde (MDA) measurement method described by Draper and Hadeley [80] was used for lipid oxidation of fresh and stored egg yolk estimation. A total of $0.5 \mathrm{~g}$ of egg yolk was diluted in $5 \mathrm{~mL}$ of TCA (20\%) with $0.5 \mathrm{~mL}$ of BHT (1\%) in absolute ethanol. After stirring for $1 \mathrm{~h}$ at room temperature, samples were centrifuged for $15 \mathrm{~min}$ at $3000 \mathrm{rpm}$. A total of $2.95 \mathrm{~mL}$ of thiobarbituric acid (TBA) $(50 \mathrm{mM})$ were added to $1.5 \mathrm{~mL}$ of solution. After incubation at $100^{\circ} \mathrm{C}$ for $10 \mathrm{~min}$, the samples were cooled at room temperature and centrifuged at $3500 \mathrm{rpm}$ for $10 \mathrm{~min}$. Absorbance was measured at $532 \mathrm{~nm}$ using an UV-visible spectrophotometer against $2 \% \mathrm{NaCl}$ (blank). Thiobarbituric acid was used as a standard. The thiobarbituric acid reactive substances (TBARS) are expressed as $\mu \mathrm{g}$ of MDA per $g$ of sample.

\subsection{Statistical Analysis}

Data were tested for 'diet' (C, L and LTP) and 'type of eggs' (fresh or stored) effects and their interaction using mixed models with compound symmetry covariance structures of SAS [81]. Interaction 'diet $x$ type of eggs' effects were not so significant for all parameters that comparisons of intra-diet means/egg type (C versus L and L vs. LTP for fresh and stored eggs separately) and intra-type of eggs/diet (fresh versus stored eggs for each diet) were not possible. Eggs were also stored without separation between yolk, albumen and shell so that all parameters were not determined on the same eggs before and after storage, but separately, on representative samples of eggs laid/diet.

Data were tested for 'diet' (C, L and LTP) using the GLM procedure (General Linear Model) of SAS according to the following model:

$$
\mathrm{Y}_{\mathrm{ij}}=\mu+\mathrm{T}_{\mathrm{i}}+\mathrm{e}_{\mathrm{ij}}
$$

where:

$Y_{i j}=$ represents the jth observation on the ith treatment

$\mu=$ overall mean

$T_{i}=$ the main effect of the ith treatment

$\mathrm{e}_{\mathrm{ij}}=$ random error present in the jth observation on the ith treatment 
When diet and/or egg type effects were significant at $\alpha<0.05$, means comparisons were tested using the CONTRAST statement of SAS [82]. The effect of storage on eggs/diet was tested using the Student T-test. Correlations between egg yolk color traits and carotenoid concentration were tested using the procedure CORR of SAS [81]. All statistical procedures were tested using SAS [81].

\section{Results and Discussion}

\subsection{Egg Physical Characteristics}

Egg physical characteristics before and after storage at $4{ }^{\circ} \mathrm{C}$ for 30 days are reported in Table 2.

Table 2. Physical characteristics of eggs before and after storage at $4{ }^{\circ} \mathrm{C}$ for one month.

\begin{tabular}{|c|c|c|c|c|c|}
\hline \multirow{2}{*}{ Parameters } & \multirow{2}{*}{ Eggs } & \multicolumn{3}{|c|}{ Diets } & \multirow{2}{*}{$p$-Value } \\
\hline & & $C^{\alpha}$ & $L^{\alpha}$ & LTP $\alpha$ & \\
\hline \multirow{2}{*}{ Egg weight, g } & Fresh & $55.48^{\mathrm{aA}}$ & $57.67 \mathrm{aA}$ & 57.09 aA & 0.07 \\
\hline & Stored & $54.08^{\mathrm{cA}}$ & $56.87^{\mathrm{aA}}$ & $56.21^{\mathrm{abA}}$ & 0.024 \\
\hline \multirow{2}{*}{ Yolk weight, $g$} & Fresh & 13.79 aA & $13.84^{\mathrm{aA}}$ & $13.86^{\mathrm{aA}}$ & 0.99 \\
\hline & Stored & $14.54^{\mathrm{aA}}$ & $14.69 \mathrm{aB}$ & $14.48^{\mathrm{aB}}$ & 0.92 \\
\hline \multirow{2}{*}{ Albumen weight, $g$} & Fresh & $33.95^{\mathrm{aA}}$ & $35.53^{\mathrm{aA}}$ & $34.73^{\mathrm{aA}}$ & 0.13 \\
\hline & Stored & $31.88^{\mathrm{bB}}$ & $34.00^{\mathrm{aA}}$ & $33.68^{\mathrm{aA}}$ & 0.046 \\
\hline \multirow{2}{*}{ Shell weight, $g$} & Fresh & $5.4^{\mathrm{aA}}$ & $6.15^{\mathrm{aA}}$ & $5.89^{\mathrm{aA}}$ & 0.16 \\
\hline & Stored & $5.2 \mathrm{cA}$ & $5.65^{\mathrm{aA}}$ & $5.58^{\mathrm{abB}}$ & 0.004 \\
\hline \multirow{2}{*}{ Shell thickness, mm } & Fresh & $0.39 \mathrm{aA}$ & $0.4^{\mathrm{aA}}$ & $0.42^{\mathrm{aA}}$ & 0.15 \\
\hline & Stored & $0.4^{\mathrm{aA}}$ & $0.42^{\mathrm{aA}}$ & $0.41^{\mathrm{aA}}$ & 0.41 \\
\hline
\end{tabular}

Note: ${ }^{\alpha} \mathrm{C}=$ Control diet; $\mathrm{L}=$ diet supplemented with ground linseed at $4.5 \%$, LTP $=$ diet supplemented with

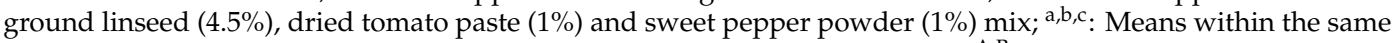
row with no different superscripts letters are not significantly different $(p>0.05) ; \mathrm{A}, \mathrm{B}$ : Means of the same parameters within the same column with no different superscripts letters are not significantly different $(p>0.05)$; Data for fresh eggs from Omri et al. [72].

As reported in our previous research study [72], dietary supplementation of $4.5 \%$ of linseeds increased $(p>0.05)$ fresh egg weight, and compared to the linseeds (L), tomato-sweet pepper mixture was without effect $(p>0.05)$. However, stored egg weight was influenced $(p<0.05)$ with dietary treatment and, for each of the four treatments, there was a slight loss of egg weight after storage at $4{ }^{\circ} \mathrm{C}$. Fresh and stored egg yolk weights were not influenced $(p>0.05)$ by dietary treatment. Dietary treatment did not affect $(p>0.05)$ the fresh eggs' albumen weight. However, LTP increased $(p<0.05)$ the stored eggs' albumen weight. Storage decreased $(p<0.05)$ albumen weight of hens fed with the control diet. The shell weight of fresh eggs was not affected $(p>0.05)$ by dietary treatment, but increased $(p<0.05)$ by L and LTP addition for stored eggs. Storage decreased $(p<0.05)$ egg shell weight of hens fed on the LTP diet. Shell thickness was affected $(p>0.05)$ neither by dietary treatment nor by storage. In this regard, Yassein et al. [83] showed that dietary addition of $5 \%$ of linseeds did not affect egg weight and albumen, yolk and shell percentages. Ahmad et al. [84] found that feeding hens with $5 \%$ of linseed did not affect egg weight (59.93 g vs. $60.47 \mathrm{~g}$ ), yolk weight (15.15 g vs. $14.81 \mathrm{~g}$ ), albumen weight (9.05 g vs. $10.51 \mathrm{~g})$, shell weight ( $8.13 \mathrm{~g}$ vs. $8.48 \mathrm{~g})$ and shell thickness $(0.39 \mathrm{~g}$ vs. $0.38 \mathrm{~mm})$.

Concerning tomato, Akdemir et al. [43] reported that the dietary supplementation of $0.5 \%$ and $1 \%$ of tomato powder did not influence yolk weight (16.59 g vs. $17.11 \mathrm{~g})$, shell weight $(6.79 \mathrm{~g}$ vs. $6.97 \mathrm{~g}$ ) and shell thickness $(0.399 \mathrm{~mm}$ vs. $0.393 \mathrm{~mm})$.

Studies on the effect of egg storage on its physical characteristics are lacking. However, Niemiec et al. [85] reported that the dietary addition of primrose, linseeds and rapeseeds at, respectively, $2.88 \%, 3.66 \%$ and $5 \%$, with or without supplementation of $200 \mathrm{mg}$ vitamin $\mathrm{E} / \mathrm{kg}$, did not affect egg weight after 20 days of storage at $12{ }^{\circ} \mathrm{C}$. A significant reduction in the egg yolk weight after storage 
was found, from $24.23 \%$ (control group) to $23.35 \%$ (primrose, linseeds and rapeseeds) and $23.18 \%$ (primrose, linseeds, rapeseeds and vitamin E).

\subsection{Egg Yolk Antioxidant Profile}

Egg yolk antioxidants [86] ( $\alpha$-carotene, $\beta$-carotene, $\beta$-cryptoxanthine, lycopene, zeaxanthine, total phenols and flavonoids) concentrations before and after storage at $4{ }^{\circ} \mathrm{C}$ for 30 days are reported in Table 3.

Table 3. Egg yolk antioxidants profile before and after storage at $4{ }^{\circ} \mathrm{C}$ for one month.

\begin{tabular}{|c|c|c|c|c|c|}
\hline \multirow{2}{*}{ Parameters } & \multirow{2}{*}{ Eggs } & \multicolumn{3}{|c|}{ Diets } & \multirow{2}{*}{$p$-Value } \\
\hline & & $\mathrm{C}^{\alpha}$ & $L^{\alpha}$ & $\operatorname{LTP} \alpha$ & \\
\hline \multirow{2}{*}{$\alpha$-carotene, $\mu \mathrm{g} / \mathrm{g}$} & Fresh & $11.0^{\mathrm{bA}}$ & $12.26^{\mathrm{aA}}$ & $12.7^{\mathrm{aA}}$ & 0.0002 \\
\hline & Stored & $11.47^{\mathrm{abA}}$ & $11.66^{\mathrm{aA}}$ & $12.03^{\mathrm{aA}}$ & 0.033 \\
\hline \multirow{2}{*}{$\beta$-carotene, $\mu \mathrm{g} / \mathrm{g}$} & Fresh & $11.2^{\mathrm{bA}}$ & $12.3^{\mathrm{aA}}$ & $12.9^{\mathrm{aA}}$ & 0.0001 \\
\hline & Stored & $11.53^{\mathrm{aA}}$ & $11.71^{\mathrm{aA}}$ & $12.18^{\mathrm{aA}}$ & 0.06 \\
\hline \multirow{2}{*}{$\beta$-Cryptoxanthine, $\mu \mathrm{g} / \mathrm{g}$} & Fresh & $12.4^{\mathrm{bA}}$ & $13.81^{\mathrm{aA}}$ & $14.42^{\mathrm{aA}}$ & 0.0001 \\
\hline & Stored & $12.59 \mathrm{aA}$ & $13.11^{\mathrm{aA}}$ & $13.45^{\mathrm{aA}}$ & 0.089 \\
\hline \multirow{2}{*}{ Lycopene, $\mu \mathrm{g} / \mathrm{g}$} & Fresh & $7.67^{\mathrm{bA}}$ & $8.42^{\mathrm{aA}}$ & $8.90^{\mathrm{aA}}$ & $<0.0001$ \\
\hline & Stored & $7.98^{\mathrm{bA}}$ & $8.09^{\mathrm{aA}}$ & $8.37^{\mathrm{aA}}$ & 0.034 \\
\hline \multirow{2}{*}{ Zeaxanthine, $\mu \mathrm{g} / \mathrm{g}$} & Fresh & $12.4^{\mathrm{bA}}$ & $13.81^{\mathrm{aA}}$ & $14.42^{\mathrm{aA}}$ & 0.0001 \\
\hline & Stored & 12.59 aA & $13.11^{\mathrm{aA}}$ & $13.45^{\mathrm{aA}}$ & 0.089 \\
\hline \multirow{2}{*}{ Total phenols, mg GAE/g $¥$} & Fresh & $1.86^{\mathrm{bA}}$ & $2.17^{\mathrm{aA}}$ & $2.16^{\mathrm{aA}}$ & 0.0034 \\
\hline & Stored & $1.57^{\mathrm{aB}}$ & $1.74^{\mathrm{aB}}$ & $1.64^{\mathrm{aB}}$ & 0.69 \\
\hline \multirow{2}{*}{ Flavonoids, mg CE/g ${ }^{£}$} & Fresh & $1.92^{\mathrm{bA}}$ & $1.53^{\mathrm{bA}}$ & $2.96^{\mathrm{aA}}$ & 0.0009 \\
\hline & Stored & $1.50^{\mathrm{aA}}$ & $1.39^{\mathrm{aA}}$ & $2.17^{\mathrm{aA}}$ & 0.38 \\
\hline
\end{tabular}

Note: ${ }^{\alpha} \mathrm{C}=\mathrm{Control}$ diet; $\mathrm{L}=$ diet supplemented with ground linseed at $4.5 \%$, LTP $=$ diet supplemented with ground linseed $(4.5 \%)$, dried tomato paste $(1 \%)$ and sweet pepper powder $(1 \%) \mathrm{mix}$; ${ }^{*}$ : Total phenols expressed in $\mathrm{mg}$ gallic acid equivalent, $\mathrm{mg} \mathrm{GAE} / \mathrm{g}$; ${ }^{£}$ : Flavonoids expressed in $\mathrm{mg}$ catechin equivalent, $\mathrm{mg} \mathrm{CE} / \mathrm{g}$; ${ }^{\mathrm{a}, \mathrm{b}, \mathrm{c}}$ : Means within the same row with no different superscripts letters are not significantly different $(p>0.05) ;{ }^{\mathrm{A}, \mathrm{B}}$ : Means of the same parameters within the same column with no different superscripts letters are not significantly different $(p>0.05)$; data for fresh eggs from Omri et al. [72].

Fresh eggs concentrations of all antioxidants were affected $(p<0.05)$ by dietary treatment. Carotenoid concentrations of fresh eggs of hens fed with control diet (C) varied from 7.7 to $12.4 \mu \mathrm{g} / \mathrm{g}$ of yolk, respectively, for lycopene and zeaxanthine [72]. These levels were in agreement with those (12.8 and $9.2 \mu \mathrm{g} / \mathrm{g} \mathrm{DM}$, respectively, for luteine and zeaxanthine) reported by Englmaierovà et al. [49] of eggs from hens fed with corn, wheat, soybean meal and alfalfa meal. Our results, were higher than those reported by Hammershøj et al. [46] who found that eggs of hens fed on a standard organic food (wheat, oats, peas, sunflower meal, fish meal) contained: $7.46 \mu \mathrm{g} / \mathrm{g}$ of lutein, $2.6 \mu \mathrm{g} / \mathrm{g}$ of zeaxanthine, $0.01 \mu \mathrm{g} / \mathrm{g}$ of $\alpha$-carotene $/ \mathrm{g}$ and $0.03 \mu \mathrm{g} / \mathrm{g}$ of $\beta$-carotene. Our results were also higher than those $(7.09 \mu \mathrm{g} / \mathrm{g}$ of luteine, $0.85 \mu \mathrm{g} / \mathrm{g}$ of cis-luteine, $7.09 \mu \mathrm{g} / \mathrm{g}$ of zeaxanthine, $0.69 \mu \mathrm{g} / \mathrm{g}$ of cis-zeaxanthine and $1.07 \mu \mathrm{g} / \mathrm{g}$ of $\beta$-carotene) reported by Kotrbáček et al. [87] for a diet containing $33 \%$ of wheat, $30 \%$ of corn and $24 \%$ of soybean meal. Studies in the literature with regard to this aspect are lacking. However, a total phenol content equal to $0.54 \mathrm{mg}$ GAE/g DM was reported by Amar et al. [88] and equal to $0.72 \mathrm{mg} \mathrm{GAE} / \mathrm{g}$ (diet based on yellow corn) and $0.66 \mathrm{mg}$ GAE/g DM (diet based on wheat) were found by Nimalaratne et al. [14]. Dietary incorporation of linseeds increased $(p<0.05)$ fresh egg yolk concentrations of carotenoid and total phenols and did not affect $(p>0.05)$ egg yolk concentration of flavonoids.

Diet with dried tomato (1\%) and sweet red pepper (1\%) mix contained four times more carotenoid than diet with linseeds (L). However, fresh egg yolk carotenoid concentrations of hens fed with $\mathrm{L}$ and LTP were not different $(p>0.05)$. Studies on the effects of linseeds on the egg yolk antioxidants profile 
are lacking. Concerning tomato, Habanabashaka et al. [89] reported that dietary incorporation of 0, 3, 6 or $9 \%$ of tomato by-products increased egg yolk concentration of lycopene from 0.01 to $0.95 \mu \mathrm{g} / \mathrm{g}$, lutein from 10.1 to $13.9 \mu \mathrm{g} / \mathrm{g}$ and of zeaxanthine from 9.4 to $12.9 \mu \mathrm{g} / \mathrm{g}$. However, Amar et al. [88] reported that dietary incorporation of $0,4,7,10$ and $13 \%$ of tomato peel increased egg yolk concentration of lycopene from $26.5 \mu \mathrm{g} / \mathrm{g}$ DM (4\%) to $42.8 \mu \mathrm{g} / \mathrm{g}$ DM $(7 \%) ; 37.6 \mu \mathrm{g} / \mathrm{g}$ DM $(10 \%)$ and $41.8 \mu \mathrm{g} / \mathrm{g}$ DM $(13 \%)$ and of $\beta$-carotene from $6.5 \mu \mathrm{g} / \mathrm{g}$ DM $(0 \%) ; 11.3(4 \%) \mu \mathrm{g} / \mathrm{g}$ DM; $17.6(7 \%) \mu \mathrm{g} / \mathrm{g}$ DM; $12.3(10 \%) \mu \mathrm{g} / \mathrm{g} \mathrm{DM}$ to $16.7 \mu \mathrm{g} / \mathrm{g}$ DM (13\%). Akdemir et al. [43] evaluated the effect of the dietary addition of $0.5 \%, 1 \%$ of tomato powder reported that an increase in egg yolk concentration of lycopene from $6.53(0.5 \%)$ to $8.05 \mu \mathrm{g} / \mathrm{g}(1 \%)$, of $\beta$ - carotene form $172 \mu \mathrm{g} / \mathrm{g}(0 \%)$ to $331 \mu \mathrm{g} / \mathrm{g}(0.5 \%)$ and $551 \mu \mathrm{g} / \mathrm{g}(1 \%)$ and of lutein from $6.85 \mu \mathrm{g} / \mathrm{g}(0 \%)$ to $7.23 \mu \mathrm{g} / \mathrm{g}(0.5 \%)$ and $9.03 \mu \mathrm{g} / \mathrm{g}(1 \%)$. Dietary incorporation of $0.1 \%, 0.2 \%, 0.4 \%$, $0.8 \%$ of paprika extract increased egg yolk concentration of total carotenoid from $3.43 \mu \mathrm{g} / \mathrm{g}(0 \%)$ to $7.7 \mu \mathrm{g} / \mathrm{g}(0.1 \%), 10.86 \mu \mathrm{g} / \mathrm{g}(0.2 \%), 14.60 \mu \mathrm{g} / \mathrm{g}(0.4 \%)$ and $16.83 \mu \mathrm{g} / \mathrm{g}(0.8 \%)$ [90]. Egg storage for one month did not affect $(p>0.05)$ the egg yolk concentrations of all carotenoids $(\alpha$-carotene, $\beta$-carotene, cryptoxanthin, lycopene and zeaxanthin) and decreased $(p<0.05)$ the total phenol concentrations of each treatment.

Reports on the effect of storage of eggs of hens fed with similar treatments to ours diets are lacking. However, Barbarosa et al. [91] reported that egg storage for 35 days at room temperature $\left(26.5^{\circ} \mathrm{C}\right)$ reduced egg yolk total carotenoid concentration from 28.55 to $22.09 \mu \mathrm{g} / \mathrm{g}$. By contrast, egg storage for 35 days at $7.9^{\circ} \mathrm{C}$ reduced total carotenoid egg yolk concentration from 28.55 to $23.57 \mu \mathrm{g} / \mathrm{g}$. Gawecki et al. [92] also reported that egg storage for 8 weeks at $2{ }^{\circ} \mathrm{C}$ did not reduce egg yolk total carotenoid concentration. However, after 15 weeks of storage, the total carotenoid concentration in the egg yolk decreased from $28.55 \mu \mathrm{g} / \mathrm{g}$ to $27.03 \mu \mathrm{g} / \mathrm{g}$.

In the present study, egg yolk antioxidant capacity was evaluated by determining egg yolk capacity to reduce $\mathrm{MO}^{6+}$ to $\mathrm{MO}^{5+}$ and $\mathrm{Fe}^{3+}$ to $\mathrm{Fe}^{2+}$. Lipid oxidative stability determined by thiobarbituric acid reactive substances (TBARS) was even higher than the concentration of MDA, which was low.

Only fresh egg antioxidant activity determined by the reduction of $\mathrm{MO}^{6+}$ to $\mathrm{MO}^{5+}$ was influenced $(p<0.05)$ by dietary treatment. Fresh egg antioxidant activity of the control group was equal to $4.48 \mathrm{mg} \mathrm{AAE} / \mathrm{g}$. Reports in the literature concerning egg yolk antioxidant activity expressed as AAE and as GAE are lacking. Fresh egg yolk concentration of MDA was not affected $(p>0.05)$ by dietary treatment. Fresh egg yolk concentration of MDA of the control treatment was equal to $0.11 \mu \mathrm{g} / \mathrm{g}$ [72]. This value was lower than the $1.17 \mu \mathrm{g} / \mathrm{g}$ reported by Englmaierovà et al. [49] and the $0.7 \mu \mathrm{g} / \mathrm{g}$ reported by Venglovská et al. [93] for fresh eggs of hens fed on corn, wheat and soybean meal. Our results were similar to those reported by Hayat et al. [94] with a mean value of $0.1 \mu \mathrm{g} / \mathrm{g}$ for fresh eggs of hens fed on corn meal and soybean meal.

The dietary addition of $4.5 \%$ of linseeds increased $(p<0.05)$ the egg yolk antioxidant capacity, but not its lipids oxidative stability $(p>0.05)$. Thus, egg enrichment with fatty acids (polyunsaturated and polyunsaturated $\omega-3$ ) through the dietary supplementation of linseeds did not reduce egg yolk lipid oxidative stability. This lipid protection against oxidation may be attributed to the increase of fresh egg yolk pigments and total phenol concentrations (Table 3). In this regard, Hayat et al. [94] reported that egg yolk MDA concentration increased from 0.1 to $0.23 \mu \mathrm{g} / \mathrm{g}(10 \%$ of linseeds flaxseed), $0.32 \mu \mathrm{g} / \mathrm{g}$ (10\% of linseeds plus $50 \mathrm{IU}$ of $\alpha$-tocopherol) and $0.28 \mu \mathrm{g} / \mathrm{g}(10 \%$ of linseeds plus $150 \mathrm{mg}$ of BHT). However, Boruta and Niemiec [95] reported that the dietary addition of $3 \%$ of linseeds with or without supplementation of $200 \mathrm{mg} / \mathrm{kg}$ of vitamin E did not affect fresh egg yolk concentration of thiobarbituric acid-reactive substances (TBARS). The dietary inclusion of $1 \%$ of dried tomato and $1 \%$ of sweet red pepper in addition to the linseeds did not improve fresh egg yolk antioxidant activity and its lipid oxidative stability $(p>0.05)$. This inefficiency of dried tomato and sweet red pepper mixture could be due to its low level of incorporation (2\%) that did not affect egg yolk concentrations of pigments, total phenols and flavonoids when compared to diet with linseeds (Table 4). 
Table 4. Egg yolk lipid oxidative status before and after storage at $4{ }^{\circ} \mathrm{C}$ for one month.

\begin{tabular}{cccccc}
\hline \multirow{2}{*}{ Parameters } & \multirow{2}{*}{ Eggs } & \multicolumn{3}{c}{ Diets } & \multirow{2}{*}{$p$-Value } \\
\cline { 3 - 5 } & & $\mathbf{C}^{\alpha}$ & $\mathbf{L}^{\alpha}$ & LTP $^{\alpha}$ & \\
\hline \multirow{2}{*}{ Antioxidant activity, mg AAE/g ${ }^{\alpha}$} & Fresh & $4.48^{\mathrm{bA}}$ & $5.07^{\mathrm{aA}}$ & $5.16^{\mathrm{aA}}$ & 0.0009 \\
& Stored & $3.68^{\mathrm{aB}}$ & $3.89^{\mathrm{aB}}$ & $3.99^{\mathrm{aB}}$ & 0.0004 \\
\hline \multirow{2}{*}{ Antioxidant activity, mg GAE/g } & Fresh & $3.14^{\mathrm{aA}}$ & $4.38^{\mathrm{aA}}$ & $4.14^{\mathrm{aA}}$ & 0.11 \\
& Stored & $1.16^{\mathrm{aB}}$ & $1.40^{\mathrm{aB}}$ & $1.58^{\mathrm{aB}}$ & 0.16 \\
\hline Thiobarbituric acid reactive & Fresh & $0.11^{\mathrm{aA}}$ & $0.14^{\mathrm{aA}}$ & $0.15^{\mathrm{aA}}$ & 0.28 \\
substances (TBARS), $\mu$ g MDA/g & Stored & $0.14^{\mathrm{bA}}$ & $0.24^{\mathrm{aA}}$ & $0.16^{\mathrm{bA}}$ & 0.01 \\
\hline
\end{tabular}

Note: ${ }^{\alpha} \mathrm{C}=$ Control diet; $\mathrm{L}=$ diet supplemented with ground linseed at $4.5 \%$, LTP $=$ diet supplemented with ground linseed $(4.5 \%)$, dried tomato paste $(1 \%)$ and sweet pepper powder $(1 \%) \mathrm{mix} ; \S$ : Antioxidant activity evaluated as phosphomolybdenum reducing power and expressed in ascorbic acid equivalent (AAE); ${ }^{*}:$ Antioxidant activity evaluated as ferric reducing power and expressed in gallic acid equivalent (GAE); $a, b, c$ : Means within the same row with no different superscripts letters are not significantly different $(p>0.05) ;{ }^{\mathrm{A}, \mathrm{B}}$ : Means of the same parameters within the same column with no different superscripts letters are not significantly different $(p>0.05)$; data for fresh eggs from Omri et al. [72].

Akdemir et al. [43] showed that the dietary addition of $0.5 \%$ and $1 \%$ tomato powder reduced egg yolk concentration of MDA from $0.33 \mu \mathrm{g} / \mathrm{g}$ (control) to $0.25 \mu \mathrm{g} / \mathrm{g}(0.5 \%)$ and $0.21 \mu \mathrm{g} / \mathrm{g}(1 \%)$. Sahin et al. [96] also reported the dietary addition of 100 and $200 \mathrm{mg}$ of lycopene $/ \mathrm{kg}$ in Japanese

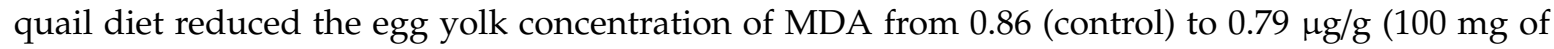
lycopene $/ \mathrm{kg}$ ) and $0.74 \mu \mathrm{g} / \mathrm{g}$ (200 mg of lycopene $/ \mathrm{kg})$. Dietary addition of carophyll, lutein or algae (chlorella) improved egg yolk the oxidative stability from $1.17 \mu \mathrm{g} / \mathrm{g}$ (control) to $1 \mu \mathrm{g} / \mathrm{g}$ (carophyll), $0.87 \mu \mathrm{g} / \mathrm{g}$ (lutein) and $0.90 \mathrm{mg} / \mathrm{kg}$ (algae) [49].

Concerning stored eggs, only antioxidant activity measured by phosphomolybdenum reduction and lipid oxidative stability were influenced $(p<0.05)$ by dietary treatment. Diet with linseeds $(4.5 \%)$ plus sweet red pepper and tomato mix $(2 \%)$ was associated with higher $(p<0.05)$ lipid oxidative stability than diet with linseeds. However, egg storage decreased $(p<0.05)$ yolk antioxidant activity but not lipid stability to the oxidation of the four treatments. In this regard, Pereira [97] reported that MDA egg yolk concentration increased from 0.52 to 0.71 and $0.90 \mu \mathrm{g} / \mathrm{g}$ after storage at $4{ }^{\circ} \mathrm{C}$ for, respectively, 60 and $90 \mathrm{j}$. By contrast, Hayat et al. [94] reported that egg storage at $4{ }^{\circ} \mathrm{C}$ for 20,40 and 60 days did not affect MDA concentration. Shahryar et al. [70] reported that $\omega-3$ and $\omega-6$ enriched eggs stored at $4{ }^{\circ} \mathrm{C}$ for 30 and 60 days increased MDA concentrations. Boruta and Niemiec [95] evaluated the effect of dietary addition of $4 \%$ rapeseed, $3 \%$ linseeds and $2 \%$ primrose, with or without supplementation of $200 \mathrm{mg} / \mathrm{kg}$ of vitamin E, on egg antioxidant status and reported that egg storage for 3 and 6 months increased yolk MDA concentration. However, vitamin E supplementation decreased egg yolk MDA concentration after 6 months of storage.

\subsection{Egg Yolk Coloration}

Egg yolk coloration before and after storage at $4{ }^{\circ} \mathrm{C}$ for one month are represented in Table 5 .

Color scores determined by the Yolk Color Fan ${ }^{\circledR}$ scale (RYCF) were affected by dietary treatment $(p<0.0001)$. Fresh egg yolk score of the control group was the lowest with a mean value of 4.67 [72]. Our values were not in agreement with 6.65 reported by Abdouli et al. [98] and 8.64 found by Lokaewmanee et al. [99] for eggs of hens fed with a similar diet to our control treatment. $b^{*}$ mean value showed that egg yolk yellow color was sufficiently intense. Our results were lower than 32.5 and 48.2 reported, respectively by, Abdouli et al. [98] and Dvorak et al. [100]. Negative mean value of $\mathrm{a}^{*}$ indicated an absence of the red hue. Higher mean values ranging from 0.05 to 13.5 were reported by Dvorak et al. [100]. L* and $C^{*}$ mean values showed that the egg yolks of hens fed with control treatment were characterized by an intense, light yellow color. Dietary incorporation of $4.5 \%$ of linseeds increased $(p<0.05)$ the egg yolk color score (RYCF). The fresh egg yolk of hens fed with linseeds tended to have a slightly more yellow, redder and less light color than the eggs of the control group. 
Correlations between the yolk color scores (RYCF), parameters determined by Chroma Meter and pigments concentrations (Table 6), showed that the yolk color scores (RYCF) and redness $\left(a^{*}\right)$ were positively correlated with all the determined pigments.

Table 5. Egg yolk coloration before and after storage at $4{ }^{\circ} \mathrm{C}$ for one month.

\begin{tabular}{|c|c|c|c|c|c|}
\hline \multirow{2}{*}{ Parameters } & \multirow{2}{*}{ Eggs } & \multicolumn{3}{|c|}{ Diets } & \multirow{2}{*}{$p$-Value } \\
\hline & & $C^{\alpha}$ & $L^{\alpha}$ & $\operatorname{LTP} \alpha$ & \\
\hline \multirow[t]{2}{*}{ RYCF } & Fresh & $4.67^{\mathrm{cA}}$ & $5.65^{\mathrm{bA}}$ & $8.2^{\mathrm{aA}}$ & $<0.0001$ \\
\hline & Stored & $4.7^{\mathrm{cA}}$ & $5.4^{\mathrm{bA}}$ & $7.53^{\mathrm{aA}}$ & $<0.0001$ \\
\hline \multirow{2}{*}{$\mathrm{L}^{*}$} & Fresh & $72.65^{\mathrm{aA}}$ & $71.63^{\mathrm{aA}}$ & $69.42^{b A}$ & $<0.0001$ \\
\hline & Stored & $73.32^{\mathrm{aA}}$ & $72.84^{\mathrm{aB}}$ & $70.47^{b B}$ & 0.003 \\
\hline \multirow[b]{2}{*}{$a^{*}$} & Fresh & $-0.59 \mathrm{bA}$ & $1.19^{\mathrm{bA}}$ & $6.59^{\mathrm{aA}}$ & $<0.0001$ \\
\hline & Stored & $0.59^{\mathrm{bA}}$ & $0.53^{\mathrm{bB}}$ & $6.44^{\mathrm{aA}}$ & $<0.0001$ \\
\hline \multirow{2}{*}{$b^{*}$} & Fresh & $62.81^{\mathrm{aA}}$ & $64.91^{\mathrm{aA}}$ & $60.28^{\mathrm{aA}}$ & 0.1 \\
\hline & Stored & $64.59 \mathrm{aA}$ & $64.06^{\mathrm{aA}}$ & $61.22^{\mathrm{bA}}$ & 0.003 \\
\hline \multirow{2}{*}{$C^{*}$} & Fresh & $62.85^{\mathrm{aA}}$ & $64.95^{\mathrm{aA}}$ & $60.70^{\mathrm{aA}}$ & 0.15 \\
\hline & Stored & $64.46^{\mathrm{aA}}$ & $64.07^{\mathrm{aA}}$ & $61.58^{\mathrm{aA}}$ & 0.06 \\
\hline
\end{tabular}

Note: ${ }^{\alpha} \mathrm{C}=$ Control diet; $\mathrm{L}=$ diet supplemented with ground linseed at $4.5 \%$, LTP $=$ diet supplemented with ground linseed ( $4.5 \%)$, dried tomato paste (1\%) and sweet pepper powder (1\%) mix; RYCF: Roche Yolk Color Fan; a,b,c Means within the same row with no different superscripts letters are not significantly different $(p>0.05)$; ${ }^{A}, \mathrm{~B}$ Means of the same parameters within the same column with no different superscripts letters are not significantly different $(p>0.05)$; data on fresh eggs from Omri et al. [72].

Table 6. Correlation between fresh and stored egg yolk coloration and carotenoid concentration.

\begin{tabular}{|c|c|c|c|c|c|c|}
\hline Parameters & Eggs & $\alpha$-Carotene & $\beta$-Carotene & $\beta$-Cryptoxanthine & Lycopene & Zeaxanthine \\
\hline \multirow{2}{*}{ RYCF } & Fresh & $0.53 * *$ & $0.55 * *$ & $0.52 * *$ & $0.57^{* * *}$ & $0.52 * *$ \\
\hline & Stored & $0.41^{*}$ & $0.39 *$ & $0.34^{*}$ & $0.40^{*}$ & $0.34^{*}$ \\
\hline \multirow{2}{*}{$\mathrm{L}^{*}$} & Fresh & $-0.56^{* *}$ & $-0.54^{* *}$ & $-0.47 *$ & $-0.58^{* * *}$ & $-0.47^{*}$ \\
\hline & Stored & -0.09 & -0.29 & -0.24 & -0.09 & -0.24 \\
\hline \multirow[b]{2}{*}{$a^{*}$} & Fresh & $0.54 * *$ & $0.52 * *$ & $0.47 *$ & $0.57^{* * *}$ & $0.47 *$ \\
\hline & Stored & $0.38 *$ & $0.37^{*}$ & 0.30 & $0.38^{*}$ & 0.30 \\
\hline \multirow{2}{*}{$b^{*}$} & Fresh & -0.12 & -0.17 & -0.018 & -0.13 & 0.018 \\
\hline & Stored & 0.13 & 0.07 & 0.02 & 0.12 & 0.02 \\
\hline \multirow[b]{2}{*}{$C^{*}$} & Fresh & -0.10 & -0.15 & 0.003 & -0.115 & 0.003 \\
\hline & Stored & 0.15 & 0.09 & 0.04 & 0.14 & 0.04 \\
\hline
\end{tabular}

However, lightness $\left(\mathrm{L}^{*}\right)$ and yellowness $\left(\mathrm{b}^{*}\right)$ were negatively correlated with all the determined pigments. Dietary supplementation of the tomato and the red pepper mixture $(2 \%)$ increased $(p<0.05)$ the RYCF score and the red hue $\left(\mathrm{a}^{*}\right)$, and decreased $(p<0.05)$ the lightness $\left(\mathrm{L}^{*}\right)$ without affecting $(p>0.05)$ the saturation $\left(C^{*}\right)$. These results are in agreement with those reported by Akdemir et al. [43] who found that dietary supplementation of $0.5 \%$ or $1 \%$ of dried tomato increased egg yolk color from 11.25 (control) to $13.08(0.5 \%)$ and $13.58(1 \%)$. The dietary addition of $130 \mathrm{~g}$ of dried tomato peel $/ \mathrm{kg}$ DM increased the egg yolk color index from 8.5 to 14.6 [88]. Habanabashaka et al. [89] reported that the supplementation of $6 \%$ of tomato waste meal increased egg yolk scores from 4.66 (control) to $9.15(6 \%)$. Salajedheh et al. [101] found that dietary incorporation of $19 \%$ of dried tomato pomace had a significant effect on egg yolk color scores which increased from 7.25 to 9.38 . Dietary addition of 50 and $100 \mathrm{~g} / \mathrm{kg}$ of dried tomato powder increased egg yolk color from 6.7 (control) to 9.7 and 10.3 for respectively, 50 and $100 \mathrm{~g} / \mathrm{kg}$ of dried tomato powder [102]. Salajedheh et al. [101], also reported that the dietary supplementation of 150 and $190 \mathrm{~g} / \mathrm{kg}$ of dried tomato powder increased egg yolk color from 7.25 (control) to, respectively, $8.50(150 \mathrm{~g} / \mathrm{kg})$ and $9.83(190 \mathrm{~g} / \mathrm{kg})$. Studies on the effect of red 
pepper powder on the egg yolk color are lacking. However, Niu et al. [90] showed that the dietary addition of $0.8 \%$ of paprika increased egg yolk color from 1.7 to 9.9. Li et al. [42] also reported that dietary supplementation of 0.3 to 4.8 or $9.6 \mathrm{ppm}$ and $0.8 \%$ of red pepper powder increased egg yolk color from 7.7 to 12.7 .

Studies on the effect of linseeds on egg yolk color are lacking. However, Yassein et al. [83] showed a decrease in yolk color related to linseed supplementation at a level of $5 \%$. Reports on $L^{*} \mathrm{a}^{*} \mathrm{~b}^{*}$ color space in response to dietary supplementation of carotenoid are also lacking.

Concerning stored eggs, with the exception of saturation $\left(C^{*}\right)$, all other parameters were influenced $(p<0.05)$ by dietary treatment. Storage of eggs of hens fed with the control diet (C) did not affect $(p>0.05)$ the yolk score and color parameters determined by colorimetry. By contrast, the storage increased $(p<0.05)$ yolk lightness $\left(\mathrm{L}^{*}\right)$ and decreased redness $\left(\mathrm{a}^{*}\right)$ of eggs corresponding to linseeds treatment $(\mathrm{L})$. However, stored eggs corresponding to the LTP- treatment were found to be less colorful (lower RYCF score) and lighter (higher $\mathrm{L}^{*}$ ) than fresh eggs. Studies on the effect of the storage on egg yolk color are lacking. However, Barbarosa et al. [91] reported that storage of $\omega-3$ enriched eggs for 35 days with or without refrigeration decreased the yolk color. This decrease became significant from the 28th day of storage for eggs stored at room temperature $\left(26.5^{\circ}\right)$. For eggs stored at $7.9^{\circ} \mathrm{C}$, egg yolk color reduction was not significant during the 35 days.

The use of dried tomato and red pepper as natural or biological antioxidants has been a new solution to reduce the supplementation of synthetic pigments as feed additives in laying hens' diets. However, the stability of these antioxidants may be affected over a long period of storage. In fact, degradation reactions (chemical, enzymatic and physical) can cause undesirable changes in the appearance, color and texture as well as in the nutrient content of the laying hens' diets. These reactions can be responsible for pigment losses during storage. These losses must be considered when formulating feed in order to avoid complaints. Also, the quality of these supplements may be affected by several factors such as tomato and pepper variety, soil, cultural practices and climate.

\section{Conclusions}

The results of this study clearly show how dietary inclusion of $4.5 \%$ of linseed significantly increased egg yolk concentrations of antioxidants profile. This dietary supplementation did not increase yolk concentration of MDA before and after storage at $4{ }^{\circ} \mathrm{C}$ for one month. Enriching linseed-supplemented feed with $1 \%$ tomato and $1 \%$ sweet red pepper did not enhance egg physical characteristics, yolk color, antioxidants profile and its lipid oxidative stability.

Author Contributions: B.O., A.S., N.A., H.A., A.D., M.L., R.R. have conceived the work. B.O., A.S., N.A., H.A., A.D., M.L. wrote the manuscript., B.O., N.A., H.A., R.R. have carried out the experimental study and analyzed the data. All authors have made a substantial contribution to revising the work, and approved it for publication.

Funding: This research received no external funding.

Conflicts of Interest: The authors declare no conflict of interest.

\section{References}

1. Anton, M.; Nau, F.; Nys, Y. Bioactive egg components and their potential uses. World's Poult. Sci. J. 2006, 62, 429-438. [CrossRef]

2. Nau, F.; Yamakawa, Y.N.Y.; Réhault-Godbert, S. Nutritional value of the hen egg for humans. Prod. Anim. Paris Inst. Natl. Rech. Agron. 2010, 23, 225-236.

3. Ruxton, C. Recommendations for the use of eggs in the diet. Nurs. Stand. 2010, 24, 47-55. [CrossRef] [PubMed]

4. Zdrojewicz, Z.; Herman, M.; Starostecka, E. Hen's egg as a source of valuable biologically active substances. Postępy Hig. Med. Doświadczalnej 2016, 70, 751-759. [CrossRef] [PubMed]

5. Heflin, L.E.; Malheiros, R.; Anderson, K.E.; Johnson, L.K.; Raatz, S.K. Mineral content of eggs differs with hen strain, age, and rearing environment. Poult. Sci. 2018, 97, 1605-1613. [CrossRef] [PubMed] 
6. Abeyrathne, E.D.N.S.; Lee, H.Y.; Ahn, D.U. Egg white proteins and their potential use in food processing or as nutraceutical and pharmaceutical agents-A review. Poult. Sci. 2013, 92, 3292-3299. [CrossRef] [PubMed]

7. Nimalaratne, C.; Schieber, A.; Wu, J. Effects of storage and cooking on the antioxidant capacity of laying hen eggs. Food Chem. 2016, 194, 111-116. [CrossRef] [PubMed]

8. Liu, H.; Zheng, F.; Cao, Q.; Ren, B.; Zhu, L.; Striker, G.; Vlassara, H. Amelioration of oxidant stress by the defensin lysozyme. Am. J. Physiol. Metab. 2006, 290, E824-E832. [CrossRef]

9. Ibrahim, H.R.; Hoq, M.I.; Aoki, T. Ovotransferrin possesses SOD-like superoxide anion scavenging activity that is promoted by copper and manganese binding. Int. J. Biol. Macromol. 2007, 41, 631-640. [CrossRef]

10. Nimalaratne, C.; Lopes-Lutz, D.; Schieber, A.; Wu, J. Free aromatic amino acids in egg yolk show antioxidant properties. Food Chem. 2011, 129, 155-161. [CrossRef]

11. Young, D.; Nau, F.; Pasco, M.; Mine, Y. Identification of hen egg yolk-derived phosvitin phosphopeptides and their effects on gene expression profiling against oxidative stress-induced Caco-2 cells. J. Agric. Food Chem. 2011, 59, 9207-9218. [CrossRef] [PubMed]

12. Lin, S.; Jin, Y.; Liu, M.; Yang, Y.; Zhang, M.; Guo, Y. Research on the preparation of antioxidant peptides derived from egg white with assisting of high-intensity pulsed electric field. Food Chem. 2013, 139, 300-306. [CrossRef] [PubMed]

13. Liu, J.; Jin, Y.; Lin, S.; Jones, G.S.; Chen, F. Purification and identification of novel antioxidant peptides from egg white protein and their antioxidant activities. Food Chem. 2015, 175, 258-266. [CrossRef] [PubMed]

14. Nimalaratne, C.; Bandara, N.; Wu, J. Purification and characterization of antioxidant peptides from enzymatically hydrolyzed chicken egg white. Food Chem. 2015, 188, 467-472. [CrossRef]

15. Lee, J.H.; Moon, S.H.; Kim, H.S.; Park, E.; Ahn, D.U.; Paik, H.-D.; Paik, H. Antioxidant and anticancer effects of functional peptides from ovotransferrin hydrolysates. J. Sci. Food Agric. 2017, 97, 4857-4864. [CrossRef]

16. Yoo, H.; Bamdad, F.; Gujral, N.; Suh, J.-W.; Sunwoo, H. High Hydrostatic Pressure-Assisted Enzymatic Treatment Improves Antioxidant and Anti-inflammatory Properties of Phosvitin. Curr. Pharm. Biotechnol. 2017, 18, 158-167. [CrossRef]

17. Abeyrathne, E.D.N.S.; Huang, X.; Ahn, D.U. Antioxidant, angiotensin-converting enzyme inhibitory activity and other functional properties of egg white proteins and their derived peptides-A review. Poult. Sci. 2018, 97, 1462-1468. [CrossRef]

18. Santini, A.; Novellino, E.; Armini, V.; Ritieni, A. State of the art of Ready-to-Use Therapeutic Food: A tool for nutraceuticals addition to foodstuff. Food Chem. 2013, 140, 843-849. [CrossRef]

19. Santini, A.; Novellino, E. To Nutraceuticals and Back: Rethinking a Concept. Foods 2017, 6, 74. [CrossRef]

20. Santini, A.; Tenore, G.C.; Novellino, E. Nutraceuticals: A paradigm of proactive medicine. Eur. J. Pharm. Sci. 2017, 96, 53-61. [CrossRef]

21. Santini, A.; Novellino, E. Nutraceuticals-Shedding light on the grey area between pharmaceuticals and food. Expert Rev. Clin. Pharmacol. 2018, 11, 545-547. [CrossRef]

22. Santini, A.; Cammarata, S.M.; Capone, G.; Ianaro, A.; Tenore, G.C.; Pani, L.; Novellino, E. Nutraceuticals: Opening the debate for a regulatory framework. Br. J. Clin. Pharmacol. 2018, 84, 659-672. [CrossRef]

23. Daliu, P.; Santini, A.; Novellino, E. From pharmaceuticals to nutraceuticals: Bridging disease prevention and management. Expert Rev. Clin. Pharmacol. 2018, 12, 1-7. [CrossRef]

24. Daliu, P.; Santini, A.; Novellino, E. A decade of nutraceutical patents: Where are we now in 2018? Expert Opin. Ther. Pat. 2018, 28, 875-882. [CrossRef]

25. Durazzo, A.; D’Addezio, L.; Camilli, E.; Piccinelli, R.; Turrini, A.; Marletta, L.; Marconi, S.; Lucarini, M.; Lisciani, S.; Gabrielli, P.; et al. From Plant Compounds to Botanicals and Back: A Current Snapshot. Molecules 2018, 23, 1844. [CrossRef]

26. Durazzo, A. Study Approach of Antioxidant Properties in Foods: Update and Considerations. Foods 2017, 6, 17. [CrossRef]

27. Durazzo, A.; Lucarini, M. A Current shot and re-thinking of antioxidant research strategy. Braz. J. Anal. Chem. 2018, 5, 9-11. [CrossRef]

28. Ngo, D.-H.; Wijesekara, I.; Vo, T.-S.; Van Ta, Q.; Kim, S.-K. Marine food-derived functional ingredients as potential antioxidants in the food industry: An overview. Food Res. Int. 2011, 44, 523-529. [CrossRef]

29. Walker, L.A.; Wang, T.; Xin, H.; Dolde, D. Supplementation of Laying-Hen Feed with Palm Tocos and Algae Astaxanthin for Egg Yolk Nutrient Enrichment. J. Agric. Food Chem. 2012, 60, 1989-1999. [CrossRef] 
30. Iskender, H.; Yenice, G.; Dokumacioglu, E.; Kaynar, O.; Hayirli, A.; Kaya, A. Comparison of the effects of dietary supplementation of flavonoids on laying hen performance, egg quality and egg nutrient profile. Br. Poult. Sci. 2017, 58, 550-556. [CrossRef]

31. Damaziak, K.; Marzec, A.; Riedel, J.; Szeliga, J.; Koczywąs, E.; Cisneros, F.; Michalczuk, M.; Łukasiewicz, M.; Gozdowski, D.; Siennicka, A.; et al. Effect of dietary canthaxanthin and iodine on the production performance and egg quality of laying hens. Poult. Sci. 2018, 97, 4008-4019. [CrossRef]

32. Surai, P.F.; Kochish, I.I. Nutritional modulation of the antioxidant capacities in poultry: The case of selenium. Poult. Sci. 2018. [CrossRef]

33. Campos, J.; Severino, P.; Ferreira, C.; Zielinska, A.; Santini, A.; Souto, S.; Souto, E.B. Linseed essential oil-Source of Lipids as Active Ingredients for Pharmaceuticals and Nutraceuticals. Curr. Med. Chem. 2018. [CrossRef]

34. Naviglio, D.; Romano, R.; Pizzolongo, F.; Santini, A.; De Vito, A.; Schiavo, L.; Nota, G.; Musso, S.S. Rapid determination of esterified glycerol and glycerides in triglyceride fats and oils by means of periodate method after transesterification. Food Chem. 2007, 102, 399-405. [CrossRef]

35. Naviglio, D.; Pizzolongo, F.; Ferrara, L.; Aragón, A.; Santini, A. Extraction of pure lycopene from industrial tomato by-products in water using a new high-pressure process. J. Sci. Food Agric. 2008, 88, 2414-2420. [CrossRef]

36. Naviglio, D.; Caruso, T.; Iannece, P.; Aragòn, A.; Santini, A. Characterization of high purity lycopene from tomato wastes using a new pressurized extraction approach. J. Agric. Food Chem. 2008, 56, 6227-6231. [CrossRef]

37. Romano, R.; Masucci, F.; Giordano, A.; Musso, S.S.; Naviglio, D.; Santini, A. Effect of tomato by-products in the diet of Comisana sheep on composition and conjugated linoleic acid content of milk fat. Int. Dairy J. 2010, 20, 858-862. [CrossRef]

38. Santini, A.; Graziani, G.; Ritieni, A. Nutraceuticals Recovery from Tomato Processing Waste and By-Products: Lycopene. In Tomatoes: Cultivation, Varieties and Nutrition; Chapter 17; (NARO Institute of Vegetables and Tea Science, National Agriculture and Food Research Organization, Ibaraki, Japan) ; Series: Food Science and Technology; Higashide, T., Ed.; Nova Science Publishers Inc.: Hauppauge, NY, USA, 2013; pp. 313-322, ISBN 978-1-62417-915-0.

39. Gervasi, T.; Pellizzeri, V.; Benameur, Q.; Gervasi, C.; Santini, A.; Cicero, N.; Dugo, G. Valorization of raw materials from agricultural industry for astaxanthin and beta-carotene production by Xanthophyllomyces dendrorhous. Nat. Prod. Res. 2017, 32, 1554-1561. [CrossRef]

40. Lucarini, M.; Durazzo, A.; Romani, A.; Campo, M.; Lombardi-Boccia, G.; Cecchini, F. Bio-Based Compounds from Grape Seeds: A Biorefinery Approach. Molecules 2018, 23, 1888. [CrossRef]

41. Goodwin, T.W. The Biochemistry of Carotenoids: Volume II, Animals, 2nd ed.; Chapman and Hall: New York, NY, USA, 1984.

42. Li, H.; Jin, L.; Wu, F.; Thacker, P.H.; Li, X.; Wang, X.; Liu, S.I.; Li, S.H.; Xu, Y. Effect of Red Pepper (Capsicum frutescens) Powder or Red Pepper Pigment on the Performance and Egg Yolk Color of Laying Hens Asian-Aust. J. Anim. Sci. 2012, 25, 1605-1610. [CrossRef]

43. Akdemir, F.; Orhan, C.; Sahin, N.; Sahin, K.; Hayirli, A. Tomato powder in laying hen diets: Effects on concentrations of yolk carotenoids and lipid peroxidation. Br. Poult. Sci. 2012, 53, 675-680. [CrossRef]

44. D'Evoli, L.; Lombardi-Boccia, G.; Lucarini, M. Influence of Heat Treatments on Carotenoid Content of Cherry Tomatoes. Foods 2013, 2, 352-363. [CrossRef]

45. Manzo, N.; Santini, A.; Pizzolongo, F.; Aiello, A.; Romano, R. Degradation kinetic (D100) of lycopene during the thermal treatment of concentrated tomato paste. Nat. Prod. Res. 2018, 21, 1-7. [CrossRef]

46. Hammershøj, M.; Kidmose, U.; Steenfeldt, S. Deposition of carotenoids in egg yolk by short-term supplement of coloured carrot (Daucus carota) varieties as forage material for egg-laying hens. J. Sci. Food Agric. 2010, 90, 1163-1171. [CrossRef]

47. Lucarini, M.; Lanzi, S.; D’Evoli, L.; Aguzzi, A.; Lombardi-Boccia, G. Intake of vitamin A and carotenoids from the Italian population-results of an Italian total diet study. Int. J. Vitam. Nutr. Res. 2006, 76, 103-109. [CrossRef]

48. Adams, C.A. Pigmenters \& poultry feeds. Feed Compd. 1985, 5, 12-14. 
49. Englmaierová, M.; Skřivan, M.; Bubancová, I. A comparison of lutein, spray-dried Chlorella, and synthetic carotenoids effects on yolk colour, oxidative stability, and reproductive performance of laying hens. Czech J. Anim. Sci. 2013, 58, 412-419. [CrossRef]

50. Leesson, S.; Caston, L. Enrichment of eggs with lutein. Poult. Sci. 2004, 83, 1709-1712. [CrossRef]

51. Fredriksson, S.; Elwinger, K.; Pickova, J. Fatty acid and carotenoid composition of egg yolk as an effect of microalgae addition to feed formula for laying hens. Food Chem. 2006, 99, 530-537. [CrossRef]

52. Karadas, F.; Grammenidis, E.; Surai, P.F.; Acamovic, T.; Sparks, N. Effects of carotenoids from lucerne, marigold and tomato on egg yolk pigmentation and carotenoid composition. Br. Poult. Sci. 2006, 47, 561-566. [CrossRef]

53. Surai, P.F.; Kochish, I.I.; Fisinin, V.I.; Kidd, M.T. Antioxidant Defence Systems and Oxidative Stress in Poultry Biology: An Update. Antioxidants 2019, 8, 235. [CrossRef]

54. Willcox, J.K.; Ash, S.L.; Catignani, G.L. Antioxidants and Prevention of Chronic Disease. Crit. Rev. Food Sci. Nutr. 2004, 44, 275-295. [CrossRef]

55. Dahan, K.; Fennal, M.; Kumar, N.B. Lycopene in the prevention of prostate cancer. J. Soc. Integr. Oncol. 2008, 6, 29-36.

56. Bohn, T. Carotenoids and Markers of Oxidative Stress in Human Observational Studies and Intervention Trials: Implications for Chronic Diseases. Antioxidants 2019, 8, 179. [CrossRef]

57. Pham-Huy, L.A.; He, H.; Pham-Huy, C. Free Radicals, Antioxidants in Disease and Health. Int. J. Biomed. Sci. 2008, 4, 89-96.

58. Andrew, R.; Izzo, A.A. Principles of pharmacological research of nutraceuticals. Br. J. Pharmacol. 2017, 174, 1177-1194. [CrossRef]

59. Jain, A.K.; Mehra, N.K.; Swarnakar, N.K. Role of Antioxidants for the Treatment of Cardiovascular Diseases: Challenges and Opportunities. Curr. Pharm. Des. 2015, 21, 4441-4455. [CrossRef]

60. Athreya, K.; Xavier, M.F. Antioxidants in the Treatment of Cancer. Nutr. Cancer 2017, 69, $1099-1104$. [CrossRef]

61. Costantini, D. Understanding diversity in oxidative status and oxidative stress: The opportunities and challenges ahead. J. Exp. Biol. 2019, 222, jeb194688. [CrossRef]

62. Shafi, S.; Ansari, H.R.; Bahitham, W.; Aouabdi, S. The Impact of Natural Antioxidants on the Regenerative Potential of Vascular Cells. Front. Cardiovasc. Med. 2019, 6, 28. [CrossRef]

63. Durazzo, A.; Lucarini, M.; Souto, E.B.; Cicala, C.; Caiazzo, E.; Izzo, A.A.; Novellino, E.; Santini, A. Polyphenols: A concise overview on the chemistry, occurrence and human health. Phyt. Res. 2019. [CrossRef]

64. Miller, E.D.; Dziedzic, A.; Saluk-Bijak, J.; Bijak, M. A Review of Various Antioxidant Compounds and their Potential Utility as Complementary Therapy in Multiple Sclerosis. Nutrients 2019, 11, 1528. [CrossRef]

65. Yeung, A.W.K.; Tzvetkov, N.T.; El-Tawil, O.S.; Bungǎu, S.G.; Abdel-Daim, M.M.; Atanasov, A.G. Antioxidants: Scientific Literature Landscape Analysis. Oxidative Med. Cell. Longev. 2019, 2019, 8278454. [CrossRef]

66. Hamilton, P.B.; Tirado, J.F.; Garcia-Hernandz, F. Deposition in egg yolks of the carotenoids from saponified and unsaponified oleoresin of red pepper (Capsicum annuum). Poult. Sci. 1999, 69, 462-470. [CrossRef]

67. Gonzalez, M.; Castaño, E.; Avila, E.; De Mejia, E.G. Effect of capsaicin from red pepper (Capsicum sp) on the deposition of carotenoids in egg yolk. J. Sci. Food Agric. 1999, 79, 1904-1908. [CrossRef]

68. Amaya, E.; Becquet, P.; Carné, S.; Peris, S.; Miralles, P. Carotenoids in Animal Nutrition; Fefana Publications: Bruxelles, Belgium, 2014; ISBN 978-2-9601289-4-9.

69. Sim, J.S.; Sunwoo, H.H. Designer eggs: Nutritional and functional significance. In Eggs and Health Nutrition; Watson, R.R., Ed.; John Wiley \& Sons: Hoboken, NJ, USA, 2002.

70. Shahryar, H.A.; Salamatdoust, R.; Chekani-Azar, S.; Ahadi, F.; Vahdatpour, T. Lipid oxidation in fresh and stored eggs enriched with dietary $\omega 3$ and $\omega 6$ polyunsaturated fatty acids and vitamin $\mathrm{E}$ and A dosages. Afr. J. Biotechnol. 2010, 9, 1827-1832.

71. Wang, Q.; Jin, G.; Wang, N.; Guo, X.; Jin, Y.; Ma, M. Lipolysis and oxidation of lipids during egg storage at different temperatures. Czech J. Food Sci. 2017, 35, 229-235.

72. Omri, B.; Chalghoumi, R.; Abdouli, H. Study of the Effects of Dietary Supplementation of Linseed, Fenugreek Seeds and Tomato-Pepper Mix on Laying Hen's Performances, Egg Yolk Lipids and Antioxidants Profiles and Lipid Oxidation Status. J. Anim. Sci. Livest. Prod. 2017, 1, 2. [CrossRef]

73. Amaya, D.B. Harvestplus Handbook for Carotenoids Analysis; International Food Policy Research Institute (IFPRI) and International Center for Tropical Agriculture (CIAT): Washington, DC, USA, 2004. 
74. Makkar, H.P.S. Antinutritional factors in foods for livestock. BSAP Occas. Publ. 1993, 16, 69-85. [CrossRef]

75. Patel, A.; Patel, A.; Patel, N.M. Estimation of flavonoid, polyphenolic content and In vitro antioxidant capacity of leaves of Tephrosiapurpurea Linn. (Leguminosae). Int. J. Pharm. Sci. Res. 2010, 1, 66-77.

76. Gutteridge, J.M. Biological origin of free radicals, and mechanisms of antioxidant protection. Chem. Interact. 1994, 91, 133-140. [CrossRef]

77. Durazzo, A. Extractable and Non-extractable Polyphenols: An Overview. In Non-extractable Polyphenols and Carotenoids: Importance in Human Nutrition and Health; Saura-Calixto, F., Pérez-Jiménez, J., Eds.; Food Chemistry, Function and Analysis No. 5; Royal Society of Chemistry: London, UK, 2018; p. 3761.

78. Prieto, P.; Pineda, M.; Aguilar, M. Spectrophotometric Quantitation of Antioxidant Capacity through the Formation of a Phosphomolybdenum Complex: Specific Application to the Determination of Vitamin E. Anal. Biochem. 1999, 269, 337-341. [CrossRef]

79. Benzie, I.F.F.; Szeto, Y.T. Total antioxidant capacity of teas by the ferric reducing/antioxidant power (FRAP) assay. J. Agric. Food Chem. 1999, 47, 633-636. [CrossRef]

80. Draper, H.H.; Hadeley, M. Malondialdehyde determination as Index of lipid peroxidation. Methods Enzym. 1990, 186, 421-431.

81. SAS: Statistical Analysis System. User's Guide Version; SAS Institute: Raleigh, NC, USA, 1989.

82. Cox, C. Delta Method. In Encyclopedia of Biostatistics; Armitage, P., Colton, T., Eds.; John Wiley \& Sons: New York, NY, USA, 1998; pp. 1125-1127.

83. Yassein, S.A.; El-Mallah, G.M.; Sawsan, M.A.; El-Ghamry, A.A.; Abdel-Fattah, M.M.; El-Harriry, D.M. Response of laying hens to dietary flaxseed levels on performance, egg quality criteria, fatty acid composition of egg and some blood parameters. Int. J. Res. Stud. Biosci. 2015, 3, $27-34$.

84. Ahmad, S.; Ahsan-Ul-Haq, Y.; Kamran, M.; Ata-Ur-Rehman, Z.; Sahail, M.U.; Shahid-Ur-Rahman. Effect of feeding whole linseed as a source of polyunsaturated fatty acids on performance and egg characteristics of laying hens kept at high ambient temperature. Braz. J. Poult. Sci. 2010, 15, 21-26. [CrossRef]

85. Niemiec, J.; Stępińska, M.; Świerczewska, E.; Riedel, J.; Boruta, A. The effect of storage on egg quality and fatty acid content in PUFA-enriched eggs. J. Anim. Feed. Sci. 2001, 10, 267-272. [CrossRef]

86. Nimalaratne, C.; Wu, J. Hen Egg as an Antioxidant Food Commodity: A Review. Nutrients 2015, 7, 8274-8293. [CrossRef]

87. Kotrbáček, V.; Skřivan, M.; Kopecký, J.; Pěnkava, O.; Hudečková, P.; Uhríková, L.; Doubek, J. Retention of carotenoids in egg yolks of laying hens supplemented with heterotrophic Chlorella. Czech J. Anim. Sci. 2013, 58, 193-200. [CrossRef]

88. Amar, B.K.; Larid, R.; Zidaini, S. Enriching Egg Yolk with Carotenoids \& Phenols. Int. J. Agric. Biol. Sci. Eng. 2013, 7, 489-493.

89. Habanabashaka, M.; Sengabo, M.; Oladunjoye, I.O. Effect of Tomato Waste Meal on Lay Performance, Egg Quality, Lipid Profile and Carotene Content of Eggs in Laying Hens. Iran. J. Appl. Anim. Sci. 2014, 4, 555-559.

90. Niu, Z.; Gao, Y.; Liu, F.; Fu, J. Influence of Paprika Extract Supplement on Egg Quality of Laying Hens Fed Wheat-Based Diet. Int. J. Poult. Sci. 2008, 7, 887-889.

91. Barbosa, V.C.; Gaspar, A.; Calixto, L.F.L.; Agostinho, T.S.P. Stability of the pigmentation of egg yolks enriched with omega-3 and carophyll stored at room temperature and under refrigeration. Rev. Bras. Zootec. 2011, 40, 1540-1544. [CrossRef]

92. Gawecki, K.; Awecki, K.; Potkanmski, A.; Lipinska, H. Effect of carophyll yellow and carophyll red added to comercial feeds for laying hens on yolk colour and its stability during short-term refrigeration. Rocz. Akad. Rol. W Pozn. 1977, 94, 85-93.

93. Venglovskà, K.; Grešáková, L'.; Placha, I.; Ryzner, M.; Cobanova, K. Effects of feed supplementation with manganese from its different sources on performance and egg parameters of laying hens. Czech J. Anim. Sci. 2014, 59, 147-155. [CrossRef]

94. Hayat, Z.; Gherian, G.; Pasha, T.N.; Khatak, F.M.; Jabbar, M.A. Effect of feeding flax and two types of antioxidants on egg production egg quality and lipid composition of eggs. J. Appl. Poult. Res. 2010, 18, 541-551. [CrossRef]

95. Boruta, A.; Niemiec, J. The effect of diet composition and length of storing eggs on changes in the fatty acid profile of egg yolk. J. Anim. Feed. Sci. 2005, 14, 427-430. [CrossRef]

96. Sahin, N.; Akdemir, F.; Orhan, C.; Kucuk, O.; Hayirli, A.; Sahin, K. Lycopene-enriched quail egg as functional food for humans. Food Res. Int. 2004, 41, 295-300. [CrossRef] 
97. Pereira, G.V.N. Inheritance of Acyl-Sugar Contents in Tomato Genotypes and Its Relationship to Foliar Trichomes and Repellence to Spider Mites Tetrancychus Evani. Ph.D. Thesis, Université de Lovaras, Minas Gerais, Brasil, 2005.

98. Abdouli, H.; Belhouane, S.; Hcini, E. Effect of fenugreek seeds on hens' egg yolk color and sensory quality. J. New Sci. 2014, 5, 20-24.

99. Lokaewmanee, K.; Komori, T.; Yamauchi, K.-E.; Saito, K. Effects on egg yolk colour of paprika or paprika combined with marigold flower extract. Ital. J. Anim. Sci. 2010, 9, 67. [CrossRef]

100. Dvorak, P.; Dolezalova, J.; Suchy, P. Photocolorimetric determination of yolk colour in relation to selected quality parameters of eggs. J. Sci. Food Agric. 2009, 89, 1886-1889. [CrossRef]

101. Salajedheh, M.H.; Ghazi, S.; Mahdavi, R.; Mozafari, O. Effects of different levels of dried tomato pomace on performance, egg quality and serum metabolites of laying hens. Afr. J. Biotechnol. 2012, 11, 15373-15379.

102. Mansoori, B.; Modirsanei, M.; Kiaei, M.M. Influence of dried tomato pomace as an alternative to wheat bran in maize or wheat based diets, on the performance of laying hens and traits of produced eggs. Iran. J. Veter. Res. 2008, 9, 341-346.

(C) 2019 by the authors. Licensee MDPI, Basel, Switzerland. This article is an open access article distributed under the terms and conditions of the Creative Commons Attribution (CC BY) license (http://creativecommons.org/licenses/by/4.0/). 